\title{
Iron deposits and catabolic properties of synovial tissue from patients with haemophilia
}

(5)

\author{
Goris Roosendaal, Marieke E. Vianen, Marion J. G. Wenting, \\ A. Cornelis van Rinsum, H. Marijke van den Berg, \\ Floris P. J. G. Lafeber, Johannes W. J. Bijlsma \\ From the University Hospital, Utrecht, The Netherlands
}

$\mathbf{H}$

aemophilic arthropathy is characterised by iron deposits in synovial tissues. We investigated the suggestion that iron plays an important role in synovial changes.

We obtained synovial tissue from six patients with haemophilia during arthroplasty, finding that brown haemosideritic tissue was often adjacent to tissue with a macroscopically normal appearance in the same joint. Samples from both types of synovial tissue were analysed histologically and biochemically to determine catabolic activity. Macroscopically haemosideritic synovium showed a significantly higher inflammatory activity than that with a normal appearance. Cultures of abnormal synovial tissue gave a significantly enhanced production of IL-1, IL-6 and TNF $\alpha$ compared with cultures of synovial tissue with a normal appearance. In addition, the supernatant fluids from the cultures showed greater catabolic activity from haemosideritic tissue, as determined by the inhibition of the synthesis of articular cartilage matrix.

We conclude that in patients with haemophilic arthropathy, local synovial iron deposits are associated with increased catabolic activity.

J Bone Joint Surg [Br] 1998;80-B:540-5.

Received 25 March 1997; Accepted after revision 21 November 1997

Haemophilia is characterised by spontaneous bleeding, mainly in the larger joints. Repeated bleeding episodes lead to synovitis and then to haemophilic arthropathy (HA) with

G. Roosendaal, MD

H. M. van den Berg, MD, PhD

Van Creveld Clinic, National Haemophilia Centre

M. E. Vianen, BA, Technician

M. J. G. Wenting, BA, Technician

F. P. J. G. Lafeber, BA, PhD

J. W. J. Bijlsma, MD, PhD, Professor

Department of Rheumatology and Clinical Immunology

A. C. van Rinsum, MD, PhD

Department of Orthopaedic Surgery

University Hospital Utrecht, PO Box 85500, 3508 GA Utrecht, The Netherlands.

Correspondence should be sent to Dr G. Roosendaal.

(C)1998 British Editorial Society of Bone and Joint Surgery 0301-620X/98/37807\$2.00 synovial and cartilage changes which result in disability. $^{1-4}$

The pathogenesis of this blood-induced cartilage damage is only partly understood, but it has been suggested that the recurrent presence of blood induces synoviocyte hypertrophy and hyperplasia with intense neovascularisation and inflammation of the synovial membrane. This results in the production of catabolic enzymes and cytokines by inflammatory cells. ${ }^{5}$ The initiating factor is not known.

One important characteristic of HA is the deposition of iron in the synovium, producing macroscopic brown haemosideritic staining. ${ }^{6-8}$ Synovial iron deposits due to intra-articular haemorrhage are also found in pigmented villonodular synovitis, ${ }^{9}$ haemangiomas of the synovial membrane ${ }^{10}$ and haemosideritic synovitis. ${ }^{11,12}$ All these disorders ultimately result in joint damage resembling $\mathrm{HA},{ }^{13}$ implying that iron deposits may be important in the pathogenesis of blood-induced cartilage damage. The intraarticular accumulation of iron, as a degradation product of haemoglobin, may be a direct stimulus for the proliferation of synoviocytes and may attract inflammatory cells which produce enzymes and cytokines leading to the destruction of articular cartilage.

We obtained synovial tissue from haemophilic patients during arthroplasty of the knee. The synovial iron deposits were found to be localised and, in the same joints, we found both synovial tissue with macroscopic haemosideritic staining containing iron deposits adjacent to white normal synovium without iron. We studied the histological and biochemical features of both types of tissue to analyse the role of iron deposits.

\section{Patients and Methods}

Synovial tissue. Six patients with severe haemophilia had biopsies during elective knee arthroplasties. Their mean age was 39 years (34 to 49). From each joint, six samples of synovial tissue with a haemosideritic appearance and six of adjacent tissue with a white normal appearance were taken. At random three of each set of samples were used for culture and biochemical analyses and three were used for light-microscopic and histological studies.

Light microscopy. The representative samples of both types of synovial tissue were fixed in phosphate-buffered 
Table I. Scoring systems for haemophiliac synovial tissue

\begin{tabular}{|c|c|}
\hline & Score \\
\hline \multicolumn{2}{|l|}{ (a) From deposits } \\
\hline \multicolumn{2}{|l|}{ Lining layer of cells } \\
\hline Discrete blue granules, nucleus still visible & 1 \\
\hline Concentrated blue granules, nucleus not visible & 2 \\
\hline \multicolumn{2}{|l|}{ Supporting layer } \\
\hline Discrete blue granules, nucleus still visible & 1 \\
\hline Concentrated blue granules, nucleus not visible & 2 \\
\hline Maximum & 4 \\
\hline \multicolumn{2}{|l|}{ (b) Inflammation } \\
\hline \multicolumn{2}{|l|}{ Diffuse with lymphocytic infiltration } \\
\hline None or only a few cells & 0 \\
\hline Definite & 2 \\
\hline Severe & 4 \\
\hline \multicolumn{2}{|l|}{ Local with dense infiltration } \\
\hline$<2$ or small infiltrates & 2 \\
\hline$>2$ or large infiltrates & 4 \\
\hline Maximum & 8 \\
\hline
\end{tabular}

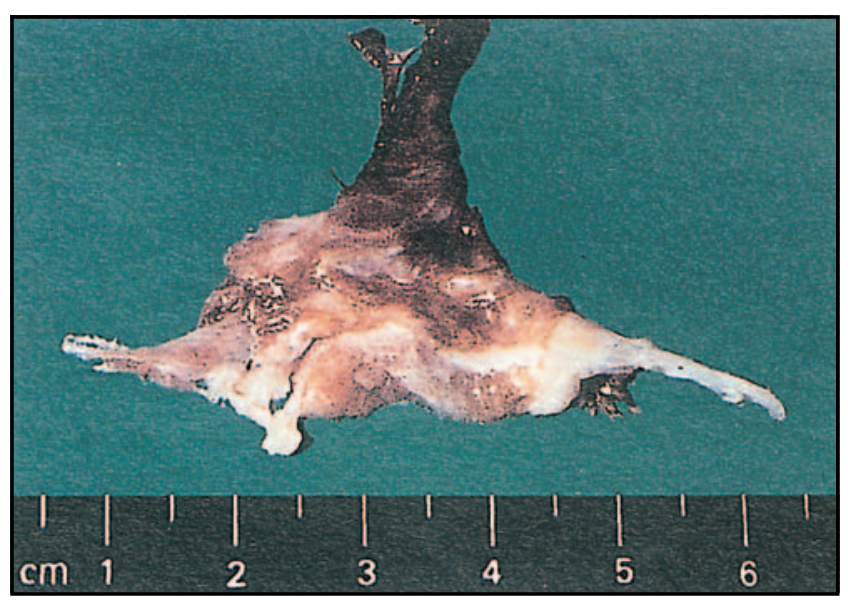

Fig. 1

A synovial tissue biopsy from a patient with HA showing areas with a brown haemosideritic appearance adjacent to tissue with a yellowish normal appearance.

(pH 7.0) 4\% formalin and, after standard processing, embedded in paraffin wax. Sections were stained with Perls' Prussian blue or haematoxylin and eosin and three randomly chosen sections of the stained samples of the two tissues for each patient were scored by two authors without knowledge of the origin of the material. Synovial iron deposits were scored as shown in Table Ia, and synovial inflammation, defined by lymphocyte infiltration, graded according to Table $\mathrm{Ib}$. The average score for the three samples was recorded as representative for each donor.

Biochemistry. From each donor, three synovial tissue samples of normal and haemosideritic tissue, weighing about $100 \mathrm{mg}(101.3 \pm 14.5$ and $101.2 \pm 15.4$, respectively) were cultured for four days in $5 \mathrm{ml}$ of culture medium (D-MEM supplemented with glutamine $(2 \mathrm{mM})$, penicillin (100 IU/ $\mathrm{ml})$, streptomycin sulphate $(100 \mu \mathrm{g} / \mathrm{ml})$, ascorbic acid $(0.85 \mathrm{mM})$ and $10 \%$ heat-inactivated human male $\mathrm{AB}+$ serum; $5 \% \mathrm{CO}_{2}$ in air, $37^{\circ} \mathrm{C}$ ). The supernatants of these cultures were rendered cell-free by centrifugation
$(1000 \times \mathrm{g}, 10$ ') and tested for catabolic activity.

Cytokine production. The presence of interleukins 1 and 6 (IL-1 and IL-6) and tumour necrosis factor alpha (TNF $\alpha$ ) in the supernatants of cultures of synovial tissue was assessed by ELISA (Medgenix, Belgium) according to the manufacturer's guidelines. Cytokine production was normalised to the wet weight of the synovial tissue.

Inhibition of articular cartilage matrix. The supernatants from tissue cultures were added to human cartilage at a $10 \%(\mathrm{v} / \mathrm{v})$ concentration and the latter cultured for four days by standard procedures. ${ }^{14}$ The synthetic activity of the chondrocytes was assessed as proteoglycan (PG) on the basis of the incorporation of sulphate during the last four hours of the experiment. ${ }^{35} \mathrm{SO}_{4}{ }^{2-}$ was used as a tracer and cetylpyridinium chloride was used to precipitate glycosaminoglycans after papain digestion of the cartilage explants. 14

The PG-synthesis, calculated from the ${ }^{35} \mathrm{SO}_{4}{ }^{2-}$ incorporation rate and the specific activity of the medium, was normalised to the wet weight of the cartilage samples and the wet weight of the synovial tissue. The supernatants of the three samples of each of the two types of synovial tissue from each donor were each tested on eight cartilage explants. The mean for the eight specimens was recorded as the average catabolic activity for each sample. The average of the three samples of each type of tissue was taken as the average for the tissue of each donor.

Statistical analysis. We calculated mean values and the SEM for the two types of synovial tissue from the six donors. Statistical evaluation of differences between means used a non-parametric test for correlated data (Wilcoxon), with significance as $\mathrm{p} \leq 0.05$.

\section{Results}

Figure 1 shows a synovial tissue biopsy with areas of haemosideritic appearance adjacent to areas of a yellowish opaline normal appearance.

Histological analysis. Figures 2 and 3 are light micrographs of representative sections of both types of synovial tissue. That with a haemosideritic appearance showed Perls' Prussian blue staining of both the lining and more central areas (Fig. 2a). The iron deposits in the lining appeared as discrete blue granules scattered throughout the cytoplasm. By contrast, those in subsynovial areas were densely concentrated aggregates, located both intracellularly and extracellularly. Perls' staining of a macroscopically normal synovium showed fewer iron deposits only in the periphery of the lining cells, leaving a clearly visible nucleus (Fig. 2b).

Haemosideritic synovial tissue showed diffuse lymphocyte infiltration, but no follicles of lymphocytes (Fig. 3a). Iron deposits were visible as dense dots in the central area, although not specifically stained. Macroscopically normal synovium (Fig. 3b) showed some neovascularisation deep to the lining layer and normal central areas with normal 


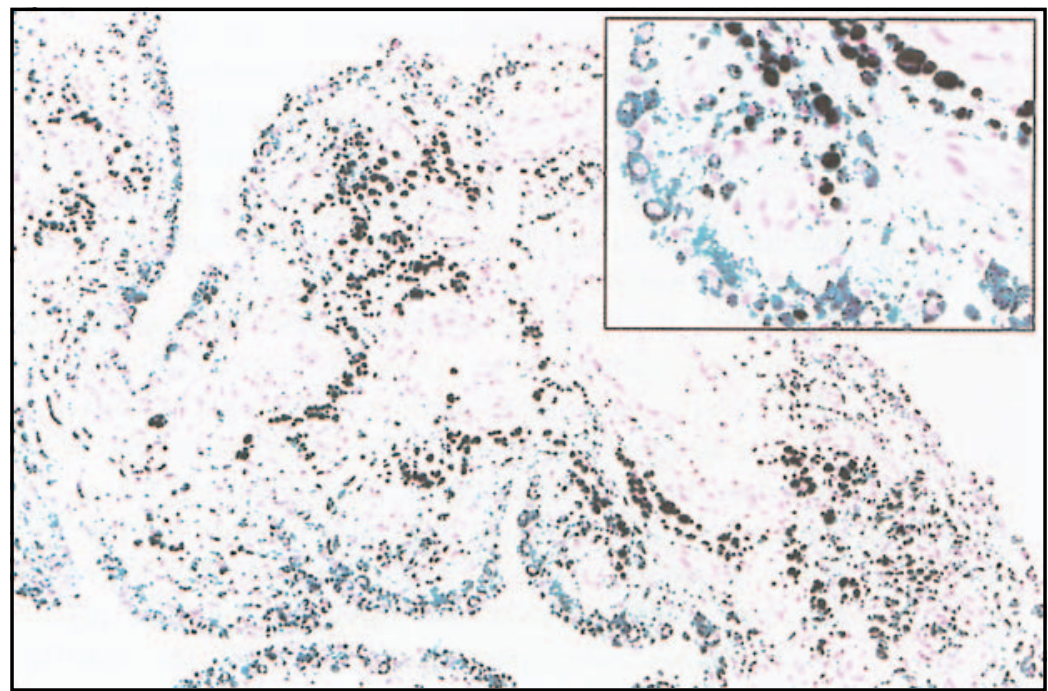

Fig. 2a

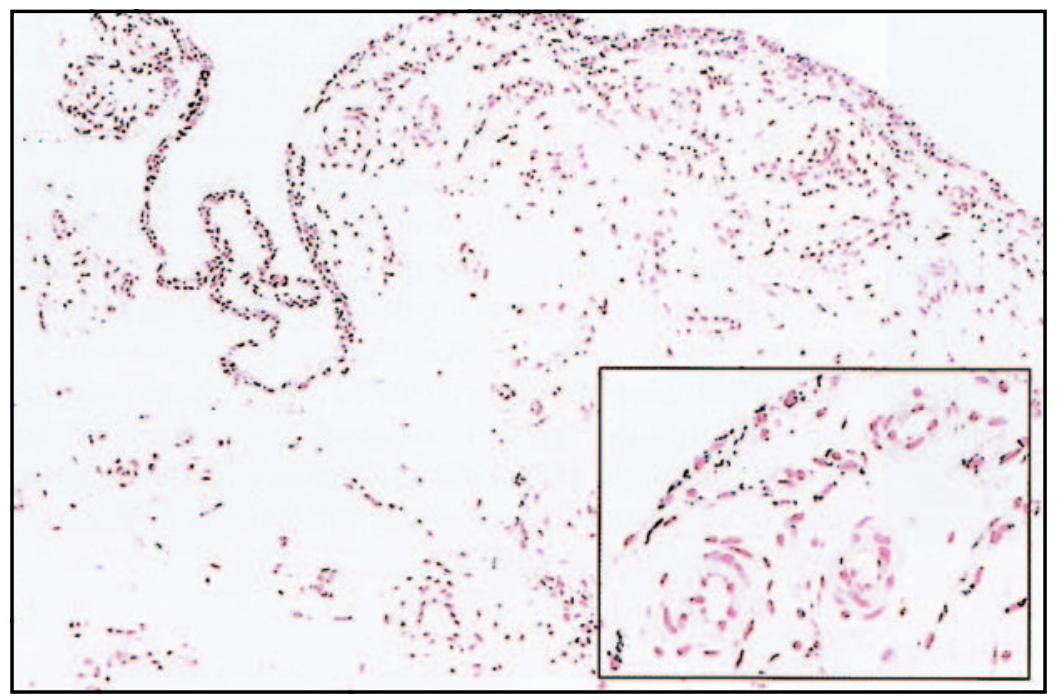

Fig. 2b

adipocytes and normal vascularisation. There were few inflammatory cells.

The relationship between iron deposits and the degree of inflammation in both types of synovial tissue is shown in Figure 4, using the scoring systems described in Table I. Macroscopically haemosideritic synovium contained significantly more iron deposits $(\mathrm{p} \leq 0.02)$ and inflammatory changes $(\mathrm{p} \leq 0.01)$ compared with macroscopically normal tissue.

Biochemical analysis. Figure 5 shows the proinflammatory cytokines, IL-6, IL-1 and TNF $\alpha$, in the supernatants of the two types of synovial tissue. Macroscopically haemosideritic tissue contained significantly more IL-6, IL-1, and $\mathrm{TNF} \alpha($ all $\mathrm{p} \leq 0.01)$.

Figure 6 shows the catabolic activity of the two types of synovial tissue, as determined by inhibition of the synthesis of articular cartilage matrix. Supernatants of cultured macroscopically haemosideritic tissue caused significantly greater inhibition of proteoglycan synthesis $(\mathrm{p} \leq 0.01)$.

\section{Discussion}

Micrographs of synovial tissue. Figure $2 \mathrm{a}-$ In haemosideritic synovium the lining cells show deposits as discrete granules, scattered throughout the cytoplasm. The deeper iron deposits are in dense intracellular and extracellular aggregates. Figure $2 b-$ Synovial tissue with a macroscopically normal appearance shows some staining of the lining cells, but iron deposits are around the periphery of the cells, leaving a clearly visible nucleus. There is much less iron in the deeper layers (Perls' Prussian blue $\times 50$, inset $\times 100$ ).

Patients with haemophilia have considerable morbidity from HA caused by recurrent intra-articular haemorrhages. We found that in all our patients the synovial tissue showed areas with a haemosideritic appearance adjacent to areas of normal appearance. This finding, to our knowledge not previously reported, provided a model for an analysis of the effect of synovial iron deposits in synovial tissue.

The macroscopic appearance corresponded closely to the histological iron deposits and, in addition, to the inflammatory and catabolic activity of the tissues. Our results show that the iron deposits at localised sites in the synovium are associated with the production of proinflammatory cytokines and an ability to inhibit the formation of human cartilage matrix. This supports the hypothesis that iron plays a leading role in the induction of synovial changes ${ }^{7}$ and the consequent production of catabolic mediators harmful to articular cartilage. It is not clear whether haemo- 


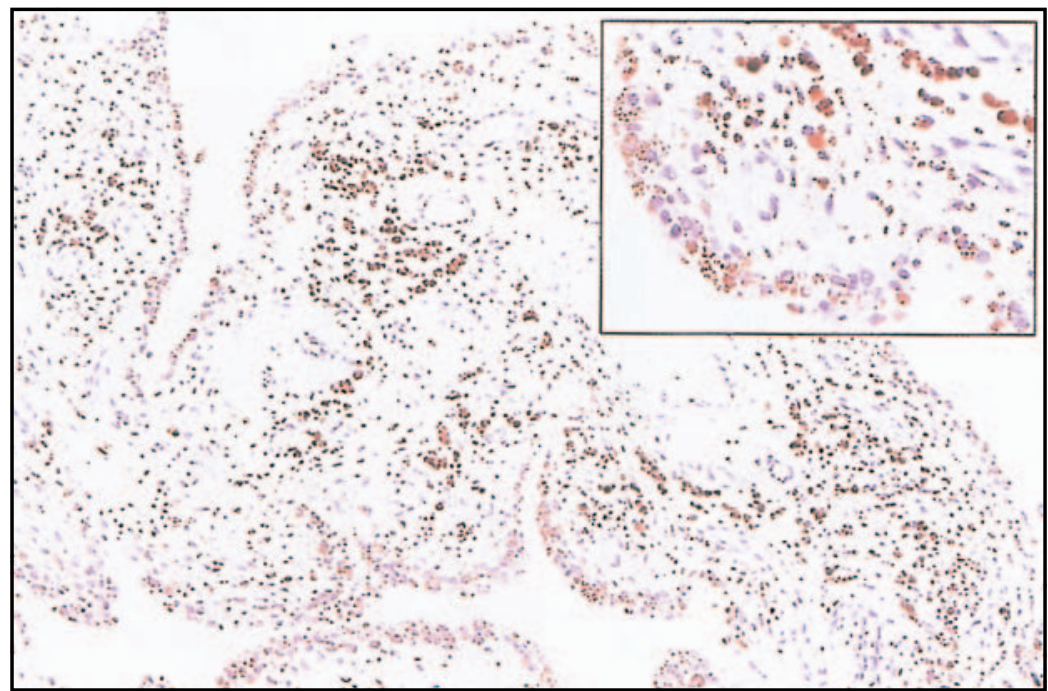

Fig. 3a

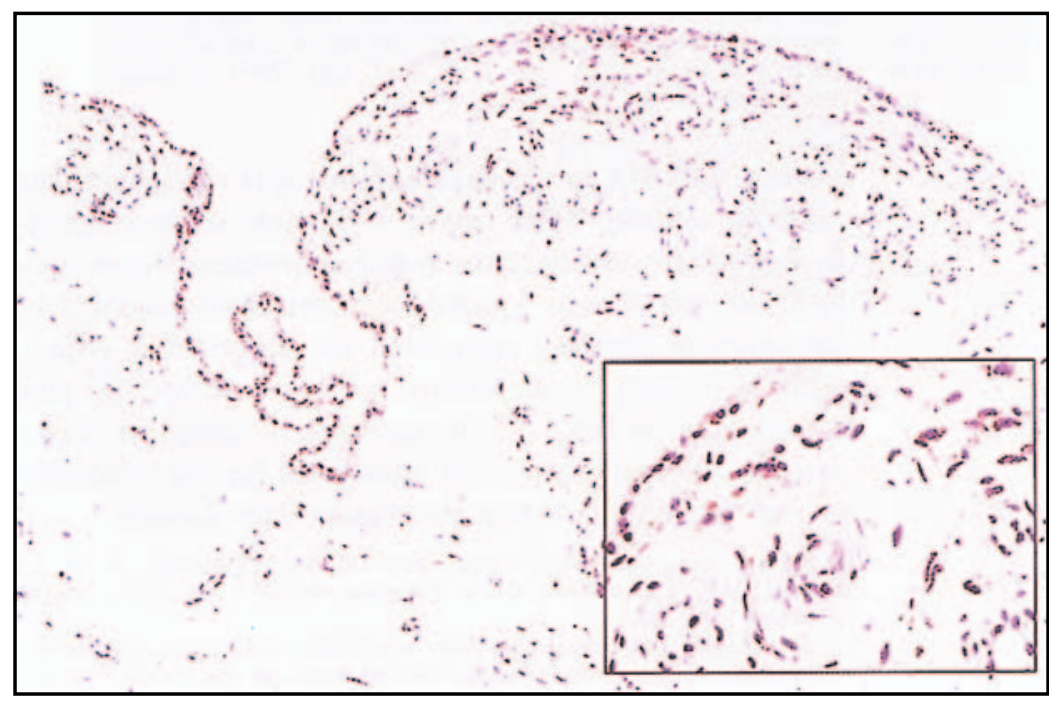

Fig. $3 b$

siderin is directly involved in the stimulation of cytokine production; it seems more likely that phagocytosis by synovial cells and blood macrophages released into the haemarthritic joint leads to the stimulation of cytokine production. An important role for iron in the induction of synovial changes has been postulated, but until now there has been little evidence to support this theory. ${ }^{7,11,15-17}$

The inflammatory changes in haemosideritic synovial tissue, as determined histologically, are mild compared with those from tissue with inflammatory joint disease such as rheumatoid arthritis, but the production in vitro of catabolic mediators such as IL-1, IL-6 and TNF $\alpha$ is comparable to that found for synovial tissue from patients with rheumatoid arthritis (unpublished work). The potential for damage by haemosideritic synovial tissue underlines the importance of the early diagnosis and treatment of chronic synovitis in haemophiliac patients.

The difference which we found between the granular iron deposits in synovial lining cells and the ovate dense
Figure $3 \mathrm{a}$ - Haemosideritic specimen showing diffuse lymphocyte infiltration and neovascularisation with no follicles of lymphocytes. Figure $3 b-$ Synovial tissue with a macroscopically normal appearance shows neovascularisation deep to the lining, cells with normal adipocytes and vascularisation, and no significant lymphocyte infiltration (haematoxylin and eosin $\times 50$, inset $\times 100)$. bodies in the central subsynovial areas confirms previous observations in HA and experimental haemarthrosis. ${ }^{18}$ Immune histochemical staining has shown that the granular siderosomes in synovial lining cells are ferritin-positive, while the ovate bodies in deeper synovial tissue do not stain for ferritin and are almost pure iron. ${ }^{7}$ It has been suggested that the death of iron-loaded cells and recurrent phagocytosis by macrophages cause the formation of the dense ovate bodies. $^{18}$

The patchy, localised aspect of the subsynovial iron deposits is of interest. It is possible that blood in the articular cavity is absorbed by the synovial lining cells, and only when these cells are saturated, are intrasynovial macrophages brought in. This may help to explain the equal spreading of the localised staining in lining and central areas. Another factor may be local haemorrhage within the synovial membrane which may cause focal macrophage activity and the localised deposition of iron as dense granules in the deeper areas. This is not corroborated by animal 


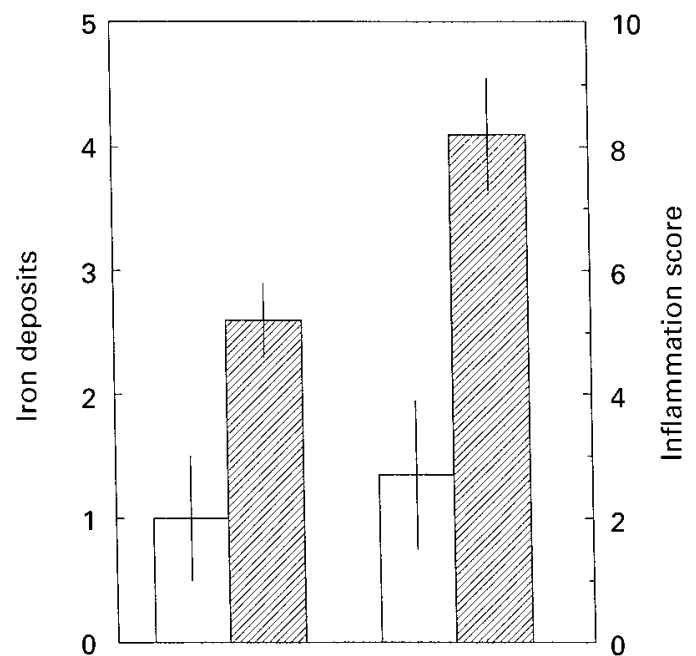

Fig. 4

Iron deposition (left) and the degree of inflammation (right) in normal-looking (open) and haemosideritic synovial tissue (hatched) quantified by the scoring system in Table I. There was significantly more iron $(\mathrm{p}=0.02)$ and inflammation $(p=0.01)$ in stained tissues.

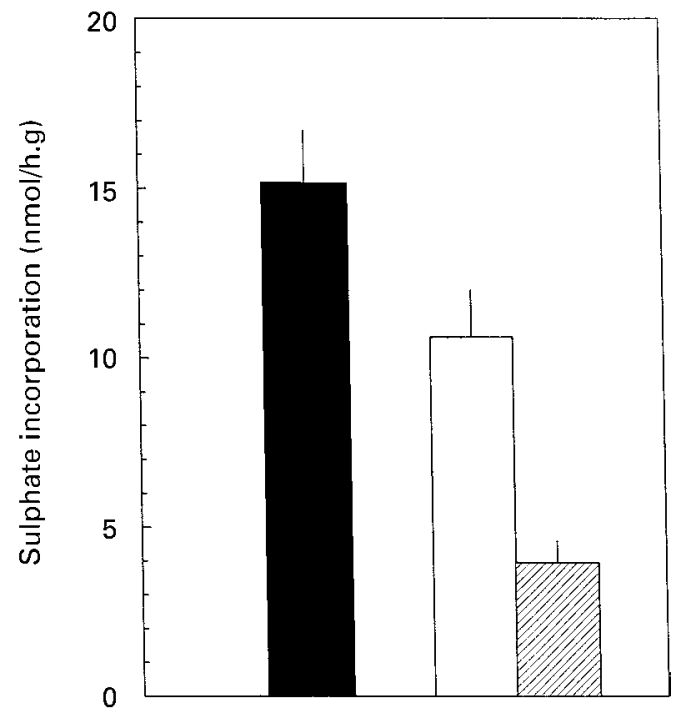

Fig. 6

The catabolic activity of supernatants of synovial tissues, as determined by inhibition of the synthesis of articular cartilage proteoglycans (PG). Macroscopically haemosideritic synovium (hatched) induced significantly greater inhibition than macroscopically normal tissue (open bar) $(\mathrm{p} \leq 0.01)$. The black bar shows control PG synthesis.

studies in which the frequent intra-articular injection of blood results in dense deeply located iron deposits, but the number of haemorrhages in the animal studies was probably less than in our haemophiliac patients. Another possible explanation for the localisation of dense synovial iron deposits may be the formation of new synovial tissue during the course of the disease, which does not contain iron deposits at the time of surgery.

We conclude that deposition of iron in the synovium of

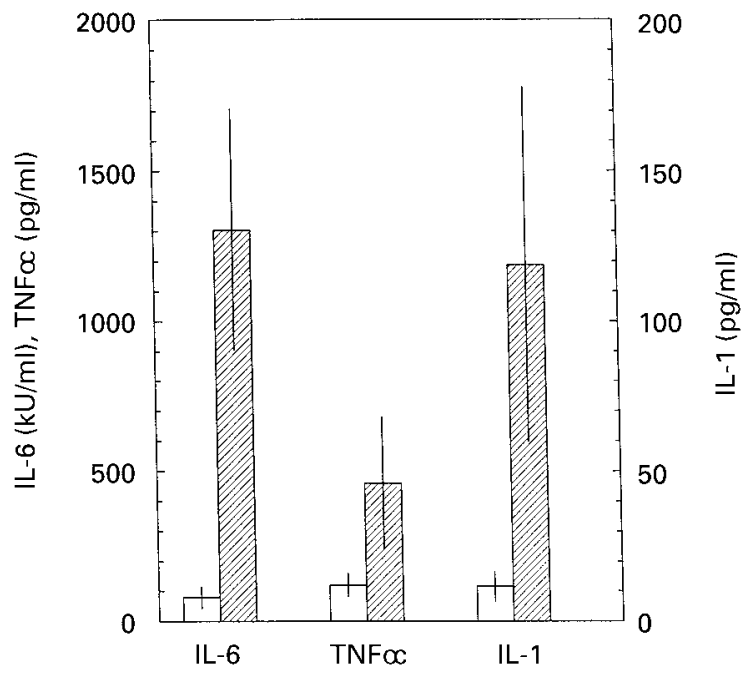

Fig. 5

The level of proinflammatory cytokines, IL-6, IL-1 and TNF $\alpha$ in supernatant from haemosideritic synovial tissue (hatched) and normal tissue (open), normalised to $100 \mathrm{mg}$ of synovial tissue. There was significantly more IL-6, IL-1, and TNF $\alpha$ in stained synovial tissues (all $\mathrm{p} \leq 0.01$ ).

patients with HA is localised and that it is associated with catabolic activity. MRI makes it possible to demonstrate hypertrophic synovial tissue with haemosiderin depositions in joints with chronic synovitis. ${ }^{19}$ Apart from reducing the frequency of bleeding episodes, ${ }^{20}$ we suggest that synoviorthesis or early synovectomy may slow down the joint deterioration in HA. ${ }^{21,22}$ The presence of significant synovial iron deposits may be an indication for synoviorthesis or synovectomy to reduce consequent joint damage.

This study was supported by a grant from Centeon, a Company of Armour and Behring. The authors thank Hanneke van Roy for her excellent technical assistance.

No benefits in any form have been received or will be received from a commercial party related directly or indirectly to the subject of this article.

\section{References}

1. Creveld Van S, Hoedemaeker PJ, Kingma MJ, Wagenvoort CA. Degeneration of joints in haemophiliacs under treatment by modern methods. J Bone Joint Surg [Br] 1971;53-B:296-302.

2. Madhok R, Bennett D, Sturrock RD, Forbes CD. Mechanisms of joint damage in an experimental model of hemophilic arthritis. Arthr Rheum 1988;31:1148-55.

3. Madhok R, York J, Sturrock RD. Haemophilic arthritis. Ann Rheum Dis 1991;50:588-91.

4. Stein H, Duthie RB. The pathogenesis of chronic haemophilic arthropathy. J Bone Joint Surg [Br] 1981;63-B:601-9.

5. Mainardi CL, Levine PH, Werb Z, Harris ED. Proliferative synovitis in hemophilia: biochemical and morphologic observations. Arthr Rheum 1978;21:137-44.

6. France MP, Gupta SK. Nonhemophilic hemosiderotic synovitis of the shoulder: a case report. Clin Orthop 1991;262:132-6.

7. Morris CJ, Blake DR, Wainwright AC, Steven MM. Relationship between iron deposits and tissue damage in the synovium: an ultrastructural study. Ann Rheum Dis 1986;45:21-6.

8. Resnick D, Oliphant M. Hemophilia-like arthropathy of the knee associated with cutaneous and synovial hemangiomas: report of 3 cases and review of the literature. Radiology 1975;114:323-6.

9. Abrahams TG, Pavlov H, Bansal M, Bullough P. Concentric joint space narrowing of the hip associated with hemosiderotic synovitis (HS) including pigmented villonodular synovitis (PVNS). Skeletal Radiol 1988;17:37-45. 
10. Roy S, Ghadially FN. Synovial membrane in experimentally-produced chronic haemarthrosis. Ann Rheum Dis 1969;28:402-14.

11. Nishiya K. Stimulation of human synovial cell DNA synthesis by iron. J Rheumatol 1994;21:1802-7.

12. Ogilvie-Harris DJ, Fornasier VL. Synovial iron deposition in osteoarthritis and rheumatoid arthritis. J Rheumatol 1980;7:30-6.

13. Axford JS. Rheumatic manifestations of haemochromatosis. Baillieres Clin Rheumatol 1991;5:351-65.

14. Lafeber FP, Vander Kraan PM, Van Roy JL, Huber Bruning O, Bijlsma JW. Articular cartilage explant culture: an appropriate in vitro system to compare osteoarthritic and normal human cartilage. Connect Tissue Res 1993;29:287-99.

15. McLardy Smith PD, Ashton IK, Duthie RB. A tissue culture model of cartilage breakdown in haemophilic arthropathy. Scand J Haematol Suppl 1984;40:215-20.

16. Safran MR, Johnston-Jones K, Kabo JM, Meals RA. The effect of experimental hemarthrosis on joint stiffness and synovial histology in a rabbit model. Clin Orthop 1994;303:280-8.
17. Zeman DH, Roberts ED, Shoji H, Miwa T. Experimental haemarthrosis in rhesus monkeys: morphometric, biochemical and metabolic analyses. J Comp Pathol 1991;104:129-39.

18. Fabry G. Ultrastructural changes in synovium and cartilage in experimental hemarthrosis in dogs. Arch Orthop Trauma Surg 1990;109: 21-9.

19. Plazanet F, du Boullay C, Defaux F, et al. Open synovectomy for the prevention of recurrent hemarthrosis of the ankle in patients with hemophilia: a report of five cases with magnetic resonance imaging documentation. Rev Rhum Engl Ed 1997;64:166-71.

20. Manco Johnson MJ, Nuss R, Geraghty S, Funk S, Kilcoyne R. Results of secondary prophylaxis in children with severe hemophilia. Am J Hematol 1994;47:113-7.

21. Wiedel JD. Arthroscopic synovectomy of the knee in hemophilia: 10to 15-year follow-up. Clin Orthop 1996;328:46-53.

22. Rodriquez-Merchan EC, Galindo E, Ladreda JM, Pardo JA. Surgical synovectomy in haemophilic arthropathy of the knee. Int Orthop 1994;18:38-41. 